granica. Ma doskonałą pamięć, z szacunkiem, chociaż krytycznie odnosi się do wcześniejszej historiografii. Jest ogromnie wyczulony na kwestie etyczne związane z godnością czlowieka nauki, profesora. Żąa szacunku dla dyscypliny naukowej, którą reprezentuje i dla uprawiających ją ludzi. Tego też wymaga od swoich uczniów i współpracowników. Jest logiczny, precyzyjny i odpowiedzialny w formułowaniu sądów naukowych, ale surowy, i nie zawsze łatwy w dyskusjach. Stąd też wzbudza u wielu respekt i posiada ogromny autorytet w środowisku historyków wychowania. Bardzo leży mu na sercu dobro i rozwój tego środowiska. Na konferencji historyków wychowania w Pułtusku w lutym 2000 r. Prof. Józef Miąso (PAN) zaproponował utworzenie organizacji grupującej i reprezentujacej potencjalnie wszystkie środowiska - Towarzystwa Historii Edukacji ${ }^{20}$. Inicjatywa ta spotkała się z pełną akceptacja zebranych. Powołano komitet założycielski, do którego weszli wszyscy uczestnicy konferencji. THE powstało w 2001 r., Profesor Miąso włączył się w prace Towarzystwa, ale odmówił przyjęcia funkcji prezesa.

Profesora Józefa Miaso ukształtowała rodzinna ziemia z jej tradycjami, dom rodzinny, nauczyciele i profesorowie, których wspomina $\mathrm{z}$ wielkim sentymentem. Wyniósł $\mathrm{z}$ domu rzetelność $\mathrm{i}$ ambicję oraz odporność na przeciwności losu, które to cechy charakteryzuja Jego drogę do wykształcenia i przebieg kariery naukowej. Stały się podstawą osiagnniętych sukcesów i autorytetu. Jego biografia jest i wyjątkowa i typowa zarazem, jak wiele życiorysów Polaków tego pokolenia, którym los przynosił wielkie zagrożenia ale także wielkie życiowe szanse. Jest bezwzględnie uczciwy i osobiście skromny, chociaż bywa też zapalczywy i uparty. Dobrze rozumie młodzież, jest wrażliwy na potrzeby ludzkie i kłopoty finansowe; służył zawsze radą i pomoca. Sam lojalny wobec ludzi źle znosi brak lojalności ze strony innych.

Kalina Bartnicka

\title{
Ogólnopolski Konkurs Prac Magisterskich z Historii Edukacji. Nagroda im. Profesora Czesława Majorka
}

W dyskusjach pokonferencyjnych XVIII Stałej Konferencji Historyków Edukacji (Kraków 1996), Profesor Cz. Majorek często powracał do pomysłu nagradzania najlepszych prac magisterskich, o tematyce zwiazanej z szeroko rozumianą historia edukacji w Polsce. Pod koniec 1999 roku, w czasie jednego ze spotkań pracowników Katedry Historii Oświaty i Wychowania, w macierzystej uczelni Profesora, Akademii Pedagogicznej w Krakowie zapadła decyzja o zorganizowaniu ogólnopolskiego konkursu. Projekt został przedstawiony na drugim, Walnym spotkaniu Towarzystwa Historii Edukacji w Warszawie w listopadzie 2001 roku, gdzie spotkał się z dużym zainteresowaniem. Wkrótce powołano jury konkursu, do którego weszli: prof. Czesław Majorek (Akademia Pedagogiczna, Kraków) - przewodniczacy, prof. Irena Szybiak (Uniwersytet Warszawski), prof. Krzysztof Jakubiak (Akademia Bydgoska) - członkowie, dr Ryszard Ślęczka (Akademia Pedagogiczna, Kraków) - sekretarz, a także przyjęto regulamin konkursu.

\section{Regulamin Konkursu}

Katedra Historii Oświaty i Wychowania Akademii Pedagogicznej w Krakowie oraz Towarzystwo Historii Edukacji organizuja ogólnopolski konkurs na prace magisterskie z najszerzej rozumianej

${ }^{20}$ A. Fijałkowski, Konferencja ,Atlas histonyczny szkót w Polsce”, Pułtusk 22-24 lutego 2000 r. [w:] Rozprawy $z$ Dziejów Oświaty, t. XL, Warszawa 2000, s. 215. 
historii edukacji, obejmującej zarówno rekonstrukcję dziejów szkolnictwa i pojedynczych szkół (elementarnych, średnich i wyższych), placówek oświaty pozaszkolnej, instytucji opiekuńczo-wychowawczych, dzieje legislacji, projektów i reform oświatowych, jak i historię myśli pedagogicznej oraz historię pedagogiki jako nauki.

\section{Cel i przedmiot konkursu}

Celem konkursu jest budzenie zainteresowań przeszłością edukacji, zamiłowań badawczych i ożywianie ruchu naukowego wśród studentów wyższych uczelni, którzy przygotowuja prace magisterskie o tematyce historyczno-edukacyjnej. Konkurs ma również wspomagać proces rekrutacji młodej kadry naukowej do pracy w katedrach i zakładach historii edukacji, w tym także kandydatów na studia doktoranckie.

Przedmiotem konkursu sa prace magisterskie wykonane i obronione w polskiej uczelni wyższej lub innej polskiej placówce akademickiego kształcenia w roku akademickim poprzedzającym rozstrzygnięcie konkursu, to jest w okresie od 1 lipca roku poprzedniego do 30 czerwca roku następnego.

\section{Zasady regulaminowe konkursu}

W konkursie może wziąc udział osoba posiadająca tytuł magistra, bez względu na ukończony kierunek studiów. Oprócz tekstu pracy należy przedstawić zwięzłą opinię swojego promotora, rekomendująca pracę do konkursu. Liczba zgłoszeń nie jest limitowana.

Praca powinna być oryginalnym dziełem jednego autora, opartym na krytycznej analizie źródeł i najnowszych opracowań, napisanym w języku polskim i udokumentowanym zgodnie z regułami warsztatu naukowego. Autor powinien dać świadectwo dobrego opanowania naukowej prozy humanistycznej i umiejętności operowania językiem - tak w sferze narracji, jak i dokumentacji.

Do konkursu przystępuje autor pracy po konsultacji ze swoim promotorem. Na stronie tytułowej pracy widnieje imię i nazwisko autora, imię i nazwisko promotora wraz z posiadanym przez niego stopniem (tytułem) naukowym, nazwą uczelni, wydziału i kierunku studiów (w pełnym brzmieniu). Dwa egzemplarze tekstu pracy łącznie z krótką opinią promotora i kserokopią dyplomu magisterskiego lub zaświadczeniem dziekanatu (dyrekcji instytutu, katedry, zakładu) o odbyciu egzaminu magisterskiego należy przesłać listem poleconym na adres: Katedra Historii Oświaty i Wychowania AP w Krakowie, ul. Podchorażych 2, 30-084 Kraków. Termin nadsylania prac: 1 lipca - 15 września każdego roku.

Konkurs rozstrzyga jury powołane przez Zarząd Towarzystwa Historii Edukacji. Jury przyznaje jedną nagrodę I stopnia w wysokości 1000 PLN, względnie dwie nagrody II stopnia - po 500 PLN każda. Fragmenty nagrodzonych prac, po stosownych korektach i ewentualnych uzupełnieniach, będa opublikowane w krajowych periodykach naukowych - historyczno-oświatowych, pedagogicznych lub historycznych. Informacje o wynikach konkursu będa opublikowane w polskich czasopismach fachowych.

Fundatorem nagrody jest Katedra Historii Oświaty i Wychowania Akademii Pedagogicznej w Krakowie, która rozporzadza specjalnym depozytem bankowym, stanowiącym kapitał zakładowy konkursu. W miarę powiększania kapitału, co stanowi przedmiot troski zarówno Katedry, jak i Zarządu Towarzystwa, wysokość nagród będzie wzrastać.

Jury konkursu w skladzie: przewodniczący, sekretarz i dwóch członków jest powoływane przez Zarząd Towarzystwa Historii Edukacji na trzyletnia kadencję. Tryb powoływania jury należy do kompetencji Zarządu, który przyjmie stosowną w tym zakresie procedurę.

Po ogólnym zapoznaniu się $z$ nadesłanymi na konkurs pracami jury dokonuje wstępnej ich kwalifikacji, po czym kieruje do recenzji najwyżej pięć wyselekcjonowanych tekstów. Każda praca jest oceniana przez dwóch recenzentów, $z$ reguły historyków wychowania, z których jeden zasiada $w$ jury. Ich zainteresowania badawcze powinny być bliskie tematyce pracy. Recenzja powinna być zwięzla i zakończona jednoznaczną konkluzją w sprawie ewentualnego nagrodzenia pracy. Swój wniosek 
recenzent uzasadnia dodatkowo punktami przy zachowaniu następujących kryteriów: bardzo dobry - 5, dobry -4 , poprawny - 2. Suma uzyskanych punktów stanowi ważną wskazówkę dla jury, które podejmuje decyzję w sprawie nagrodzenia danej pracy. Wykonanie recenzji nie jest honorowane. Decyzje jury wykonuje administrator konkursu, który powiadamia o niej zainteresowanego i uruchamia wypłatę nagrody. Równocześnie odsyła uczestnikom konkursu ich prace (jeden egzemplarz pracy nagrodzonej pozostaje $w$ archiwum konkursu).

\section{Kontakt}

Czynności administracyjne zwiąane z konkursem prowadzi Katedra Historii Oświaty i Wychowania Akademii Pedagogicznej w Krakowie przy czynnym współudziale Zarządu Towarzystwa Historii Edukacji. Z ramienia Katedry osoba odpowiedzialna jest dr Ryszard Ślęczka, który zarazem pełni funkcję sekretarza. W sprawach dotyczących konkursu należy kierować zapytania na adres: Dr Ryszard Ślęczka, Katedra Historii Oświaty i Wychowania AP, ul. Podchorążych 2, 30-084 Kraków; tel.: 0 prefix 12 6626241; e-mail: ryslen@wsp.krakow.pl

\section{Przebieg Konkursu}

Pierwsza edycja konkursu pod nazwą „Ogólnopolski Konkurs na Prace Magisterskie z Historii Edukacji" odbyła się w roku akademickim 2001/2002. Jury zakwalifikowało wówczas następujące prace:

Studenci Cesarskiego Uniwersytetu w Warszawie w latach 1869 -1904, jako grupa akademicka i w życiu miasta - autor Ewelina Tylińska, promotor prof. Kalina Bartnicka (Uniwersytet Warszawski).

Działalność opiekuńczo-wychowawcza i katechetyczna Sióstr Serafitek w Makowie Podhalańskim - autor s. Erminia Anna Jusiel, promotor prof. Henryka Kramarz (Wyższa Szkoła Filozoficzno-Pedagogiczna „Ignatianum" w Krakowie).

Szkoła powszechna w Morawicy jako placówka państwowa prowadzona przez Siostry Felicjanki w latach 1880 - 1950 - autor s. Bogumiła Moczko, promotor prof. Henryka Kramarz (Wyższa Szkoła Filozoficzno-Pedagogiczna „Ignatianum” w Krakowie).

Do współpracy, jako recenzentów, zaproszono prof. Danutę Dryndę, prof. Juliana Dybca, prof. Andrzeja Meissnera, prof. Zygmunta Rutę, dr hab. Leszka Zasztowta, dr Andrzeja Klisia, którzy dokonali wnikliwej oceny nadesłanych prac. Uwzględniając opinie wyżej wymienionych, jury postanowiło przyznać pierwsza nagrodę pani Ewelinie Tylińskiej za prace napisaną pod kierunkiem prof. Kaliny Bartnickiej, obronioną na Uniwersytecie Warszawskim.

W drugiej edycji konkursu, w roku akademickim 2002/2003, jury rekomendowano trzy prace magisterskie, które spełniały podstawowe kryteria regulaminowe. Były to:

Rola rodziny $i$ nauczania domowego w utrzymaniu tożsamości narodowej Polaków na terenie zaboru rosyjskiego $w$ drugiej potowie XIX wieku i w poczatkach wieku XX w swietle pamiętnikarstwa - autor Monika Nawrot, promotor dr hab. Krzysztof Jakubiak (Akademia Bydgoska).

Publicystyka wychowawcza Marii Ilnickiej prezentowana na lamach "Bluszcza" w latuch 1865 - 1894 - autor Dorota Waligóra, promotor dr hab. Krzysztof Jakubiak (Akademia Bydgoska).

Praca spoteczna, dziatalność naukowa, oświatowa i filantropijna dr Jana Serafina Rode w Tomaszowie Mazowieckim na przetomie XIX i XX wieku - autor Marcin Kitel, promotor prof. Teresa Wróblewska (Akademia Świętokrzyska w Kielcach, Filia w Piotrkowie Trybunalskim).

W gronie recenzentów drugiej edycji konkursu znaleźli się: prof. Julian Dybiec, prof. Wiesław Jamrożek, prof. Jan Krukowski, prof. Władysława Szulakiewicz, dr Andrzej Kliś. Po zapoznaniu się z nadesłanymi recenzjami, jury podjęło decyzję o nagrodzeniu pracy magisterskiej pani Moniki Nawrot zatytułowanej „Rola rodziny i nauczania domowego w utrzymaniu tożsamości narodowej Polaków na terenie zaboru rosyjskiego $w$ drugiej połowie XIX wieku j w początkach wieku XX w świetle pamiętnikarstwa". 
Podczas trwania drugiego etapu nieoczekiwanie zmarł jeden z pomysłodawców i twórców konkursu, prof. Czesław Majorek. Kapituła konkursu postanowiła zaproponować przewodnictwo jury prof. Zygmuntowi Rucie z Akademii Pedagogicznej z Krakowa i nadać nowe brzmienie konkursowi, odtąd będzie on nosił nazwę - Ogólnopolski Konkurs Prac Magisterskich, Nagroda imienia Profesora Czesława Majorka.

\section{Profesor Czesław Majorek 1938-2002}

Uczony, nauczyciel i pedagog, profesor zwyczajny w Katedrze Historii Oświaty i Wychowania Akademii Pedagogicznej w Krakowie. Przez szereg lat współpracowal z krakowskim oddziałem Komisji Nauk Pedagogicznych PAN i Instytutem Historii Nauki i Techniki PAN w Warszawie. Uczestniczył w pracach kilku zagranicznych instytucji i organizacji naukowych, m.in. International Standing Conference for the History of Education (ISCHE) i International Society of History Didactics. Dwukrotnie zasiadał we władzach ISCHE i zainicjował druga w Polsce stałą konferencję tej organizacji, która odbyła się w Krakowie w sierpniu 1996 r.

Profesor Cz. Majorek urodził się 27 września 1938 r. w Pleśnej koło Tarnowa. Tutaj uczęszczal do szkoły podstawowej a następnie podją naukę w Liceum Pedagogicznym w Tarnowie. Ukończył Studium Nauczycielskie w Gorzowie Wielkopolskim, studia magisterskie na Wydziale Humanistycznym Uniwersytetu Gdańskiego i doktoranckie w Wyższej Szkole Pedagogicznej w Krakowie. Należał do tych, którzy w całości poświęcili swoje życie nauce. Stopień doktora nauk humanistycznych uzyskał w 1968 broniąc publicznie dysertacji na temat „System kształcenia nauczycieli szkół ludowych w Galicji doby autonomicznej 1871-1914". Przez kolejnych siedem lat przygotowywał się do habilitacji, którą zakończył w 1975 r. przyznaniem stopienia doktora habilitowanego nauk humanistycznych, w oparciu o monografię „Książki szkolne Komisji Edukacji Narodowej”. W 1986 r. otrzymał z rak Przewodniczącego Rady Państwa tytuł naukowy profesora nadzwyczajnego nauk humanistycznych, a w 1997 r. powolany został na stanowisko profesora zwyczajnego w Katedrze Historii Oświaty i Wychowania, Wyższej Szkoły Pedagogicznej w Krakowie (obecnie Akademii Pedagogicznej w Krakowie).

Badania naukowe prowadzone przez Profesora skupiały się na dziejach polskiego szkolnictwa, oświaty i myśli pedagogicznej XVIII - XX wieku. Prof. Cz. Majorek zajmował się także problematyką programów i podręczników doby Komisji Edukacji Narodowej i okresu zaborów oraz współczesnymi orientacjami w badaniach historyczno-edukacyjnych na świecie i rodzimą dydaktyką historii.

W dorobku naukowym Profesora ważne miejsce zajmują trzy książki: Metodyka nauczania historii w szkole podstawowej (Warszawa 1988), Historia utylitarna i erudycyjna: szkolna edukacja historyczna w Galicji 1772 - 1918 (Warszawa 1990) i Dydaktyka historii (Warszawa 1993, drugie wydanie 1994), a także liczne artykuły, w których zawarte zostały własne przemyślenia i poglądy badawcze historyka edukacji. Doniosłe znaczenie dla dyscypliny naukowej uprawianej przez Profesora miały artykuły: Przezwycięzenie diaspory. Wspótczesne tendencje w rozwoju historii wychowania (Zeszyty Naukowe UJ, Prace Pedagogiczne, Kraków 1987), Wspótczesna koncepcja historii wychowania jako nauki (Rozprawy z Dziejów Oświaty 1989), Innowacje pedagogiczne jako przedmiot badań historii wychowania (Zeszyty Naukowe UJ, Prace Pedagogiczne 1991), Warsztat badawczy historyka wychowania dziejów najnowszych (Stan i perspektywy historii wychowania, Poznań 1996), Rola badań biograficznych w rekonstruowaniu dziejów pedagogicznych (Galicja i jej dziedzictwo, t. IX, Rzeszów 1997).

Ponadprzeciętne możliwości intelektualne i uzdolnienia, Profesor Czesław Majorek pragnąl przekazać swoim uczniom i studentom, a ogólnopolski konkurs prac magisterskich z historii edukacji jest tego dobitnym przykładem. Wypada wyrazić nadzieję, że laureaci ogólnopolskiego konkursu prac z historii edukacji przyczynia się do rozwoju historii wychowania jako subdyscypliny polskiej pedagogiki.

Ryszard Ślęczka 